\title{
Integration between Antagonistic Fungi and Bacteria for Controlling of Peanut Pod Rot Incidence and Occurrence of Aflatoxigenic fungi
}

\section{Zeinab N. Hussien ${ }^{1}$ and Ahmed M. Gomaa ${ }^{2}$}

\author{
${ }^{I}$ Plant Pathol. Res. Inst., Agric. Res. Center (ARC), Giza., Egypt \\ ${ }^{2}$ Central Laboratory of Residue Analysis of Pesticides and Heavy Metals in Foods, Ministry of \\ Agriculture and Land Reclamation, Giza, Egypt.
}

Received: 15 August 2020 / Accepted 20 Oct. 2020 / Publication date: 25 Oct. 2020

\begin{abstract}
Peanuts are infected with many diseases affecting the productivity, especially pod rot diseases caused by many fungi as well as aflatoxigenic fungi (Aspergillus flavus and Aspergillus parasiticus) which conceder a major health and food safety problem in the worldwide. In this study, Trichoderma harzianum, Trichoderma viride, Pseudomonas fluorescens, Pseudomonas putida and Bacillus subtilis were tested alone and in combinations for their effect as biocontrol against peanut pod rot pathogenes (Fusarium moniliforme, Fusarium solani, Macrophomina phaseolina, Rhizoctonia solani and Sclerotium rolfsii) and aflatoxigenic fungi (Aspergillus flavus and Aspergillus parasiticus). The fungal and bacterial isolates which have not to reverse effect between them were used in this study. In vitro studies, the highest antagonistic effect against the tested pathogenic fungi was shown by $P$. fluorescens followed by $T$. viride (Tv 5) and B. subtilis. In greenhouse and field experiments the isolets of selscted biocontrol againt beside standard consisting of fungicide (Rizolex-T) were evaluated for peanut pod rots as well as incidence of $A$. flavus, A. parasiticus and peanut aflatoxin contaminations. In this respect, all tested biocontrol agents and their mixture had a significant effect in reducing peanut pod rots incidence compared to the control. Pseudomonas fluorescens alone was superior followed by $T$. viride (Tv 5) and B. subtilis in reducing of peanut pod rots incidence. While the mixture of $P$. fluorescens and T. viride (Tv 5) gives the best effect in reducing of peanut pod rots incidence compared to other treatments and their effect was the nearest one to Rizolex-T effect in reduction of diseases incidence. Regard to aflatoxigenic fungi and aflatoxin contamination, isolates of $A$. flavus were more invasive to peanut pod than $A$. parasiticus. The most effective treatment was the mixture of $P$. fluorescens and $T$. viride (Tv 5) which gave the least incidence of $A$. flavus and A. parasiticus and reduced preharvest aflatoxins contamination compared to other treatments including fungicide. The highest pod yield obtained with the mixture of $T$. viride (Tv 5) and B. subtills, followed by $T$. viride (Tv 5) and $P$. fluorescens compared with other biocontrol agents while Rizolex-T gave the highest pod yield at all in the two seasons 2017 and 2018. This study conclusion that, the application of more than one antagonists of diverse origin consider a reliable means of reducing diseases and increasing the reliability of biological control.
\end{abstract}

Keywords: Bioagents, Biocontrol agent, Trichoderma harzianum, Trichoderma viride, Pseudomonas fluorescens, Pseudomonas putida, Basillus subtilis, Aspergillus flavus and Aspergillus parasiticus Aflatoxin and Crop safety

\section{Introduction}

Peanut, (Arachis hypogaea L.) is one of the most export and locally consumed crops in Egypt. Pod rots disease considered among the most destructive disease attacking peanuts and causing quantitative and qualitative losses of yield in Egypt. Meanwhile, aflatoxin contamination caused by the ubiquitous Aspergillus group of fungi is a major production constraint and is responsible for huge economic losses to the farming community and trade that makes it is one of the most challengers facing the peanut producers (Felicia et al., 2008 and Kifle et al., 2016). Aspergillus flavus and A. parasiticus were the predominant fungi infected peanut before harvest (Mahmoud and Gomaa, 2015). Aflatoxins are toxic secondary metabolites produced by some species of the Aspergillus fungus (Calvo and Cary, 2015). Aspergillus flavus and A. parasiticus are the most common species associated with aflatoxin

Corresponding Author: Ahmed M. Gomaa, Central Laboratory of Residue Analysis of Pesticides and Heavy Metals in Foods, Ministry of Agriculture and Land Reclamation, Giza, Egypt.

E-mail: ahmedmamdouh1@gmail.com 
contamination of peanut crops (Mahmoud, 2004). Aflatoxin B1 is the most toxic and potent carcinogen and the exposure to aflatoxin B1 leads to liver cancer and strongly associated with stunting and immune suppression in children (Mossanda, 2015).

Due to the environment need to more regulations and increasing of organic agriculture besides the danger of chemical control which resulted from farmers apply increasing amounts of fungicides and pesticides to avoid devastating harvest losses. Which poses risks to environmental and human health, and contributes to the increasing incidence of fungal resistance to chemical fungicides. It is therefore imperative that we find alternative approaches to crop protection. One popular suggestion is to increase the efficacy of biocontrol, which is the use of living organisms to control plant disease vectors (Price $e t$ al., 2015, Mahmoud et al., 2016, Hawkins et al., 2018 and Ng et al., 2019)

Bacillus and Pseudomonas were considered as an important genus of plant growth-promoting rhizobacteria (PGPR) (Mishra et al., 2013, Bhimeshwari et al., 2018, Muhammad et al., 2018 and Wang et al., 2018). Pseudomonas fluorescens is considered as an important antagonistic bacteria, the maximum of their antagonistic effect produced in vitro by $\mathrm{HCN}$, salicylic acid siderophores such as pyoverdine (pseudo action) pyochelin, pyrrolnitrin (antibiotic) and Beta-1,3 gluconase (Bhimeshwari et al., 2018). Also, B. subtilis can induce resistance by stimulation of phytoalexins production and increasing the activity of lytic enzymes (Wang et al., 2018). While, in general, fungal antagonists depend mainly on physical contact with their pathogen besides their ability to secretion analyses enzymes (Muhammad et al., 2018).

Biological control is a recognized method of controlling several plant diseases. Most of the studies on biological control of plant pathogens deal with single biocontrol agents as the antagonist to a single pathogen. While single biocontrol agent is not likely to be active in all soil environments or against all pathogens that attack the host plant and control of a wide spectrum of pathogens under a wide range of environmental conditions. This could be overcome by developing strain mixtures with superior biocontrol activity (Mishra et al., 2011). Consequently, the application of a mixture of introduced biocontrol agents would more closely mimic the natural situation and might broaden the spectrum of biocontrol activity, enhance the efficacy and reliability of biological control (Mishra et al., 2011 and 2013). Previous studies on combinations of biocontrol agents for plant diseases have included mixtures of fungi (Datnoff et al., 1995), mixtures of fungi and bacteria (Mishra et al., 2013 and Mahmoud et al., 2016), and mixtures of bacteria (Raupach and Kloepper, 1998).

With the hypothesis that the combination of two entirely different antagonists would enhance the level of disease management, this study was conducted to evaluate the effect of mixed compatible efficient antagonists of fungi (Trichoderma) and bacteria (Pseudomonas and Bacillus) and testing their efficacy against peanut pod rot incidence, aflatoxigenic fungi, and peanut aflatoxin contaminations under artificial inoculation in greenhouse and field conditions.

\section{Materials and Methods}

\section{Source of pathogenic fungi:}

The fungal isolates used throughout this study were previously isolated by Mahmoud and Gomaa, (2015) from diseased peanut pods and their pathogenic capabilities were also confirmed.

\section{Preparation of fungal inoculum:}

(A):Inocula of Fusarium moniliforme, Fusarium solani, Macrophomina phaseolina, Rhizoctonia solani and Sclerotium rolfsii were prepared using sorghum - coarse sand - water $(2: 1: 2 \mathrm{v} / \mathrm{v})$ medium. The ingredients were mixed, bottled and autoclaved at 15 pounds/ sq. inch for $2 \mathrm{~h}$. Each bottle of the sterilized medium was inoculated with a $5 \mathrm{~mm}$ fungal growth disc obtained from the periphery of the 5-day-old culture of each fungus. The infested media were incubated at $28^{\circ} \mathrm{C}$ for 15 days before used for soil infestation.

(B): Inocula of aflatoxigenic fungi, i.e. Aspergillus flavus and A. parasiticus were prepared, as described by Mahmoud and Gomaa, (2015) by growing each isolate on potato dextrose agar (PDA) medium for 7 days at $27^{\circ} \mathrm{C}$. Fungal spores were released from culture surface using hair camel brush and sterilized water containing $0.1 \%$ agar to prepare spore suspension of $4 \times 10^{6}$ spores $/ \mathrm{ml}$ for artificial infestation of soil. 


\section{Soil Infestation:}

Two different methods were used for soil infestation with the tested pathogens throughout this study:

(A): The inoculum of $F$. moniliforme, F. solani, M. phaseolina, $R$. solani and S. rolfsii, were mixed thoroughly with soil surface of each pot, at the rate of $2 \% \mathrm{w} / \mathrm{w}$, and were covered with a thin layer of sterilized soil for studying pod rots complex diseases. Pots containing infested soil were irrigated and kept for 10 days until sowing.

(B): Infestation with the conidial suspension at the rate of $10 \mathrm{ml}\left(4 \times 10^{4} \mathrm{spore} / \mathrm{ml}\right)$ per $\mathrm{kg}$ of soil from a mixture of A. flavus and A. parasiticus. The infestation was carried out, 30 days after sowing, to study the effect of aflatoxigenic fungi and aflatoxin contaminations (Mahmoud, 2004).

\section{Disease assessment}

(A) At harvest, the percentage of pod rot was recorded. Four categories for apparent symptoms of pod rot beside the healthy pods were adopted according to Mahmoud (2004): a) Rhizoctonia rot, pods with a dry brown lesion, b) Fusarium rot, pods with pink discoloration and c) complex rot pod with general breakdown resulting from many fungi.

$$
\text { Pod rot categories }(\%)=\begin{aligned}
& \text { Number of rotted pods } \\
& \text { Number of total pods }
\end{aligned} \quad x 100
$$

(B) Aflatoxigenic fungi, which associated with the four categories, were isolated after harvesting according to Mahmoud (2004). Seeds fruits were shelled and the seed was surface-disinfested for three minutes in $1 \%$ sodium hypochlorite and plated on potato dextrose agar (PDA) medium (4 plates in 4 replicates, 5 seeds per dish). Plates were examined after 7 days from incubated at $27^{\circ} \mathrm{C}$. The identification of the isolates was carried out based on taxonomic criteria for these fungi as described by Maren and Johan (1988).

\section{Determination of aflatoxins:}

The extraction and determination of aflatoxins was carried out according to Malone et al. (2000) with accordance to VICAM manul guidance for using immuinoaffinaty colum together with Fluorometer Series-4 (VICAM 1. P, USA), figure no. 1 sumerizes the sample preparation procedure.

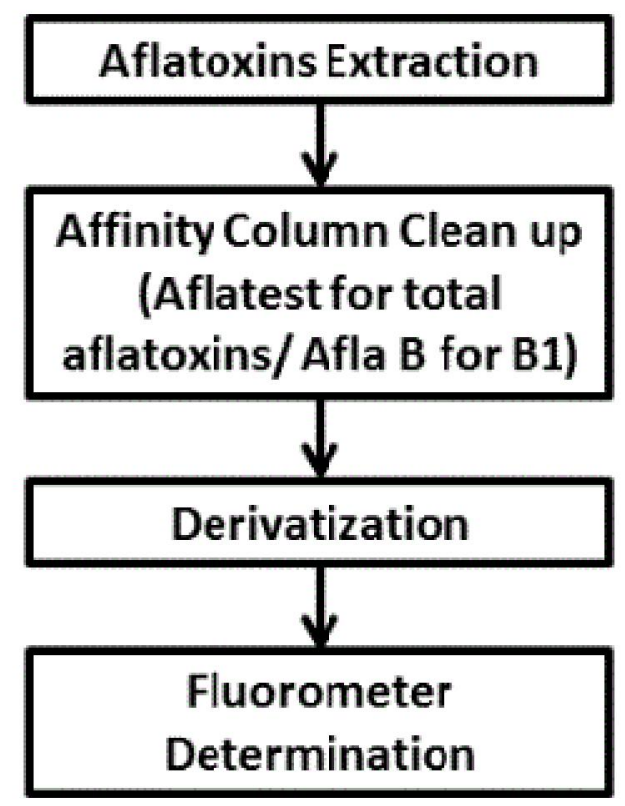

Fig. 1: Aflatoxin sample preparation procedure 


\section{The sources of biocontrol agents:}

Five known isolates of P. fluorescens (Pf5), P. putida, B. subtilis (Bs1), Brevibacterium carei and Bacillus amyloliquefcciens were obtained from Mahmoud, (2014). However, the tested bioagents included antagonistic fungal isolates i.e. Trichoderma viride and Trichoderma harzianum, were obtained from Onion, Garlic and Oil Crops Diseases Res. Dept., Plant Pathology Res. Inst., Agric., Res. Center Giza, Egypt.

\section{Testing of compatibility of fungal and bacterial biocontrol agents:}

The method described by Mahmoud et al. (2016) was used for in-vitro testing. Five mm size sterilized paper (Whatman paper No. 1) discs impregnated with a bacterial isolate suspension containing $10^{6} \mathrm{CFU} / \mathrm{ml}$ (prepared in $0.1 \mathrm{M} \mathrm{Mg} \mathrm{SO}$ ) of individual isolates were placed at $5 \mathrm{~mm}$ apart from one side of a Petri plate filled with the growth media. The bacterial isolates were allowed to grow for $24 \mathrm{hr}$ at $26 \pm 2^{\circ} \mathrm{C}$. Five $\mathrm{mm}$ diameter plug from a 5- day-old culture of Trichoderma isølate was placed on the opposite side of the plate. After 5 days incubation at $26 \pm 2^{\circ} \mathrm{C}$ the zone of inhibition was estimated. Three replications were considered for each treatment.

\section{Evaluation of biocontrol agents in vitro:}

\subsection{Effect of antagonistic fungi:}

Two discs ( $5 \mathrm{~mm}$ diam.) of plain agar culture of both antagonistic fungi and pathogenic fungi ( $F$. moniliforme, F. solani, M. phaseolina, R. solani and Sclerotium rolfsii) were inoculated (7-day-old) opposite to each other $1 \mathrm{~cm}$ apart from the dish edge $(9 \mathrm{~cm}$ diameter) containing $10 \mathrm{ml}$ PDA medium. The dishes were inoculated with one disc of mycelial growth from the same fungi as the control treatment. Four replicates were used for each particular treatment and then incubated at $26^{\circ} \mathrm{C} \pm 2$ for 57 days. Percentage of the fungal growth reduction $(\mathrm{X})$ was calculated using the following formula:

$$
\mathrm{X}=[(\mathrm{A}-\mathrm{B}) / \mathrm{A}] \mathrm{x} 100
$$

Where: A: Diameter of pathogenic fungi growth without biocontrol agents (control).

B: Diameter of pathogenic fungi growth with biocontrol agents.

\subsection{Effect of antagonistic bacteria:}

Bacillus subtilis and P. fluorescens antagonists were tested in this study. Plats of PDA medium were streaked $1 \mathrm{~cm}$ apart at one side of the dish edge with a given antagonistic bacteria and incubated for $24 \mathrm{hrs}$ at $26^{\circ} \mathrm{C} \pm 2$. Then, the same plate was inoculated at the opposite side, $1 \mathrm{~cm}$ apart from the dish edge, with a disc (5 mm diam.) from F. moniliforme, M. phaseolina, $R$. solani and Sclerotium rolfsii of 4-day-old plain agar culture. Plates control inoculated with one disc of mycelial growth of Fusarium moniliforme, Macrophomina phaseolina, Rhizoctonia solani and Sclerotium rolfsii in the absence of bacteria were prepared as a control. The percentage of the fungal growth reduction was calculated as mentioned before.

\section{Preparation of biocontrol agents:}

Bacterial suspensions $\left(1 \times 10^{6} \mathrm{CFU} / \mathrm{ml}\right)$ were prepared by dilution plate assay as described by Mahmoud, (2014). The tested antagonistic fungal isolates were prepared as an adjusted suspension with approx. 5 X $10^{8}$ conidia/ml as described by Mahmoud, (2014).

\section{Methods of application:}

The both kind of biocontrol agents (bacteria and fungi) have applied either alone or mixed as a foliar spray after 20 days and soil drench after 40 days. While fungicide Rhizolex-T 50\% (Tolclofosmethyl $20 \%$ + thiram $30 \%$ ) were applied as soil treatment at the rate of $3 \mathrm{~kg} / \mathrm{fed}$ after 30 and 60 days.

\section{Evaluation of biocontrol agents under greenhouse conditions:}

Pot experiments were carried out in order to study the effect of biocontrol agents in controlling peanut pod rots incidence (\%), the frequency of A. flavus, A. parasiticus and peanut seed contaminations with aflatoxin. The experiment was carried out at Agric. Res. Center, Giza. Peanut seeds were sown in $50 \mathrm{~cm}$-diameter pots containing sterilized soil previously infested with a mix of $F$. moniliforme, M. phaseolina, $R$. solani and $S$. rolfsii $(2 \% \mathrm{w} / \mathrm{w})$. Ten seeds were sown per pot, five replicate (pots) were used for each treatment. The biocontrol agents and fungicides were applied as 
mentioned before. Disease assessment was recorded as a percentage of pod rots incidence.

\section{Evaluation of biocontrol agents under field conditions:}

The field experiments were performed at Nubaria, during 2017 and 2018 seasons to study the effect biocontrol agents in controlling peanut pod rots incidence, the frequency of $A$. flavus, A. parasiticus and peanut seed contaminations with aflatoxin. The selected fields considered were known to have a natural infestation with pod rots pathogens. The biocontrol agents were applied as mentioned before. Seeds were sown on the first week of April with $10 \mathrm{~cm}$ spacing between hills. Cultural practices and fertilization for the peanut crop were applied as recommended. The fungicide Rhizolex-T50\% was applied as previously mentioned under the experimental unit area was $21 \mathrm{~m}^{2}$ (1/200 fed.). The treatments were arranged in a completely randomized block design with four replicates. Disease assessment was recorded as mentioned before.

\section{Statistical analysis:}

The data were statistically analyzed by analysis of variance (ANOVA) using the Statistical Analysis software "COStat 6.4" (CoStat, 2005). Means were separated by the least significant difference (LSD) test at $\mathrm{P} \leq 0.05$ levels.

\section{Results}

\section{Compatibility of fungal and bacterial biocontrol agents:}

Table (1) shows that the compatibility of Trichoderma isolates with bacterial biocontrol agents varied greatly according to the isolates. In this respect, Th 1 , Th 2 , Th $6, \operatorname{Tv} 1, \operatorname{Tv} 3, \operatorname{Tv} 4$ and $\operatorname{Tv} 5$, were compatible with $P$. fluorescens (Pf5) and exhibited no antagonistic interaction against it. Moreover, Th1, Th 5, Th 6, Tv 3, Tv 4 and Tv 5, showed a similar trend with B. subtilis (Bs1). While Th 1, Th 3, Th 6, Tv 1, Tv 3, Tv 4 and Tv 5, were compatible with $P$. putida (PP). only both of Th 6, Tv 5 were compatible with $B$. carei $(\mathrm{Bc})$. Based on these results, Trichoderma (Th $1, \operatorname{Th} 6, \operatorname{Tv} 3, \operatorname{Tv} 4$ and Tv 5), P. fluorescens (Pf5), B. subtilis (Bs1) and P. putida (PP) were evaluated in vitro for their antagonistic potential against tested pathogenic fungi (Table 2).

Table 1: Test of compatibility of biocontrol agents.

\begin{tabular}{|c|c|c|c|c|c|}
\hline Biocontrol agents & $\begin{array}{c}P . \\
\text { fluorescens } \\
\text { (Pf5) }\end{array}$ & $\begin{array}{l}\text { P. putida } \\
\text { (PP) }\end{array}$ & $\begin{array}{l}\text { B. carei } \\
\text { (Bc) }\end{array}$ & $\begin{array}{c}B . \\
\text { amyloliquefcciens } \\
\text { (Ba) }\end{array}$ & $\begin{array}{c}\text { B. subtilis } \\
\text { (Bs1) }\end{array}$ \\
\hline T. harzianum (Th 1) & + & + & - & + & + \\
\hline T. harzianum (Th 2) & + & - & - & - & - \\
\hline T. harzianum (Th 3) & - & + & - & - & - \\
\hline T. harzianum (Th 4) & - & - & - & - & - \\
\hline T. harzianum (Th 5) & - & - & - & - & + \\
\hline T. harzianum (Th 6) & + & + & + & - & + \\
\hline T. viride (Tv 1) & + & + & - & - & - \\
\hline T. viride (Tv 2) & - & - & - & + & - \\
\hline T. viride $(\operatorname{Tv} 3)$ & + & + & - & + & + \\
\hline T. viride (Tv 4) & + & + & - & - & + \\
\hline T. viride (Tv 5) & + & + & + & - & + \\
\hline T.a viride (Tv 6$)$ & - & - & - & + & - \\
\hline
\end{tabular}

Compatible $=$ inhibition zone $<1 \mathrm{~mm}(+)$ Non-compatible= inhibition zone $>1 \mathrm{~mm}(-)$.

\section{Screening of biocontrol control potential in vitro:}

Five isolates of Trichoderma (Th 1, Th 6, Tv 3, Tv 4 and Tv 5) in addition to three bacteria $(P$. fluorescens, $P$. putida and B. subtilis) were evaluated in vitro for their antagonistic effect against tested pathogenic fungi (Table 2).

$P$. fluorescens gave the high significant antagonistic effect against the tested pathogenic fungi followed by $T$. viride (Tv 5) and B. subtilis. However, T. viride (Tv 3), T. harzianum (Th 6) and $P$. putida give a moderate effect against tested pathogenic fungi. While both of $T$. viride (Tv 4) and $T$. harzianum (Th 1) had a little effect. 
Table 2: Antagonistic effect of biocontrol agents on the percentage of liner growth reduction (\%).

\begin{tabular}{|c|c|c|c|c|c|c|c|}
\hline Biocontrol agents & $\begin{array}{c}R . \\
\text { solani }\end{array}$ & $\begin{array}{c}F . \\
\text { moniliforme }\end{array}$ & $\begin{array}{c}F . \\
\text { solani }\end{array}$ & $\begin{array}{c}M . \\
\text { phaseolina }\end{array}$ & $\begin{array}{c}S . \\
\text { rolfsii }\end{array}$ & $\begin{array}{c}\text { A. } \\
\text { flavus }\end{array}$ & $\begin{array}{c}A . \\
\text { parasiticus }\end{array}$ \\
\hline T. harzianum (Th 1) & 13.33 & 17.78 & 17.78 & 22.22 & 26.67 & 18.16 & 19.33 \\
\hline T. harzianum (Th 6) & 23.44 & 30.11 & 29.00 & 29.56 & 31.56 & 30.77 & 31.61 \\
\hline T. viride (Tv 3$)$ & 22.33 & 27.22 & 26.44 & 25.00 & 26.11 & 27.82 & 29.91 \\
\hline T. viride (Tv 4) & 11.11 & 20.00 & 22.22 & 27.78 & 27.78 & 20.43 & 24.15 \\
\hline T. viride (Tv 5) & 26.67 & 33.90 & 33.33 & 31.11 & 33.33 & 35.04 & 36.23 \\
\hline P. fluorescens & 28.89 & 40.00 & 38.89 & 32.22 & 36.67 & 40.85 & 42.27 \\
\hline P. putida & 22.44 & 29.44 & 28.33 & 26.78 & 30.11 & 30.11 & 30.97 \\
\hline B. subtilis & 24.60 & 33.67 & 30.56 & 30.00 & 32.44 & 34.39 & 33.22 \\
\hline L.S.D. 5\% & 1.02 & 0.53 & 1.03 & 1.02 & 1.05 & 0.86 & 1.03 \\
\hline
\end{tabular}

\section{Evaluation of biocontrol agents under greenhouse conditions:}

\subsection{On peanut pod rots incidence:}

Two selected fungal isolates and three bacterial isolates beside standard consisting of Rizolex-T (fungicide) were evaluated for peanut pod rots control under greenhouse conditions (Table 3).

Table (3) shows that all tested biocontrol agents and their mixture had a significant effect in reducing peanut pod rots incidence compared to the control. Pseudomonas fluorescens alone was superior followed by $T$. viride ( $\mathrm{TV} 5$ ) and $B$. subtilis in reducing peanut pod rots incidence.

The present data indicated that when supply compatible mixing of fungi and bacteria give more activity in control of peanut pod rots. In this respect, the mixture of P. fluorescens and T. viride (Tv 5) gives the best effect in reducing of peanut pod rots incidence compared to other treatments except for fungicide treatment.

Data also showed that the mixture of $T$. viride (Tv 5) and P. fluorescens was the nearest one to the Rizolex-T effect in the reduction of disease incidence (Table 3 ).

Table 3: Effect of biocontrol agents on peanut pod rots incidence under greenhouse conditions.

\begin{tabular}{lcccc}
\hline \multirow{2}{*}{ Biocontrol agents } & \multicolumn{3}{c}{ Disease incidence (\%) } & Apparent \\
\cline { 2 - 4 } & $\begin{array}{c}\text { Dry brown } \\
\text { lesion }\end{array}$ & $\begin{array}{c}\text { Pink } \\
\text { discoloration }\end{array}$ & $\begin{array}{c}\text { General } \\
\text { breakdown }\end{array}$ & $\begin{array}{c}\text { healthy } \\
\text { (\%) }\end{array}$ \\
\hline T.harzianum (Th 6)+P. fluorescens & 10.14 & 0.80 & 13.87 & 75.19 \\
T.harzianum (Th 6)+ P. putida & 12.82 & 1.30 & 15.82 & 70.06 \\
T.harzianum (Th 6)+ B. subtilis & 10.64 & 1.13 & 14.92 & 73.31 \\
T. harzianum (Th 6) & 11.62 & 0.57 & 14.85 & 72.96 \\
T. viride (Tv 5)+P. fluorescens & 6.67 & 0.44 & 10.18 & 82.71 \\
T. viride (Tv 5)+P. putida & 10.78 & 0.74 & 15.15 & 73.33 \\
T. viride (Tv 5)+B. subtilis & 8.92 & 0.54 & 13.00 & 77.54 \\
T. viride (Tv 5) & 9.95 & 0.62 & 13.22 & 76.21 \\
P. fluorescens & 9.54 & 0.35 & 12.55 & 77.56 \\
$\boldsymbol{P}$ putida & 12.54 & 1.78 & 16.04 & 69.64 \\
B. subtilis & 11.13 & 0.96 & 13.21 & 74.70 \\
Rizolex-T 50\% & 6.00 & 0.28 & 9.01 & 84.71 \\
Control & 15.07 & 2.06 & 17.79 & 65.08 \\
L.S.D. 5\% & 2.11 & 0.08 & 2.03 & 2.25 \\
\hline
\end{tabular}

3.2. On the frequency of $\boldsymbol{A}$. flavus, $\boldsymbol{A}$. parasiticus and peanut seed contaminations with aflatoxin:

Two selected fungal isolate and three bacterial isolates beside of Rizolex-T (fungicide) were evaluated for the occurrence of $A$. flavus, A. parasiticus and aflatoxin content in peanut pods under greenhouse conditions (Table 4).

Generally, all tested biocontrol agents and their mixture had an effect in reducing the frequency of aflatoxigenic fungi. The occurrence of $A$. flavus was higher than that of $A$. parasiticus in all treatments whether any of them was infested separately or in the mixture (Table 4). In respect to separate treatment, $P$. fluorescens followed by $T$. viride (Tv 5) and B. subtilis give the highest reduction of the frequency of aflatoxigenic fungi as well as peanut seed contaminations with aflatoxin. While in general, the compatibility between fungi and bacteria led to more effective in reducing the frequency of aflatoxigenic fungi and seed content of aflatoxin whether total aflatoxin or $\mathrm{B}_{1}$. Regard to this point, the 
mixture of $P$. fluorescens and T. viride (Tv 5) gives the best effect in reducing the frequency of aflatoxigenic fungi and peanut seed contamination wih aflatoxin.

Table 4: Effect of biocontrol agents on the frequency of A. flavus, A. parasiticus and aflatoxin contaminations in peanut seed under greenhouse conditions.

\begin{tabular}{|c|c|c|c|c|c|c|c|c|c|c|}
\hline \multirow{3}{*}{ Biocontrol agents } & \multicolumn{3}{|c|}{ A. flavus } & \multicolumn{3}{|c|}{ A. parasiticus } & \multicolumn{4}{|c|}{$\begin{array}{l}\text { A. flavus }+A . \\
\text { parasiticus }\end{array}$} \\
\hline & \multirow{2}{*}{$\begin{array}{l}* A . f \\
\%\end{array}$} & \multicolumn{2}{|c|}{$\begin{array}{l}\text { Aflatoxin } \\
\text { (ppb) }\end{array}$} & \multirow{2}{*}{$\underset{\%}{* * \mathbf{A} . \mathbf{p}}$} & \multicolumn{2}{|c|}{$\begin{array}{l}\text { Aflatoxin } \\
\text { (ppb) }\end{array}$} & \multirow{2}{*}{$\begin{array}{c}\text { A.f } \\
\%\end{array}$} & \multirow{2}{*}{$\begin{array}{c}\text { A.p } \\
\%\end{array}$} & \multicolumn{2}{|c|}{$\begin{array}{l}\text { Aflatoxin } \\
\text { (ppb) }\end{array}$} \\
\hline & & $\mathbf{B}_{1}$ & $\begin{array}{l}\text { Total } \\
\text { AFT }\end{array}$ & & $\mathbf{B}_{1}$ & $\begin{array}{l}\text { Total } \\
\text { AFT }\end{array}$ & & & $\mathbf{B}_{1}$ & $\begin{array}{l}\text { Total } \\
\text { AFT }\end{array}$ \\
\hline $\begin{array}{l}\text { T.harzianum }(\text { Th 6)+P. } \\
\text { fluorescens }\end{array}$ & 25 & 50 & 57 & 15 & 0 & 0 & 20 & 15 & 90 & 99 \\
\hline T.harzianum $($ Th 6)+P. putida & 40 & 100 & 112 & 25 & 80 & 89 & 50 & 30 & 200 & 219 \\
\hline T.harzianum (Th 6)+ B. subtilis & 35 & 90 & 99 & 25 & 40 & 45 & 40 & 30 & 170 & 188 \\
\hline T. harzianum (Th 6) & 45 & 170 & 185 & 35 & 140 & 156 & 50 & 35 & 210 & 233 \\
\hline$T$. viride (Tv 5)+P. fluorescens & 20 & 30 & 34 & 5 & 0 & 0 & 15 & 10 & 70 & 77 \\
\hline T. viride (Tv 5) $+P$. putida & 25 & 80 & 85 & 15 & 0 & 0 & 25 & 20 & 100 & 110 \\
\hline T. viride $(\mathrm{Tv} 5)+B$. subtilis & 30 & 80 & 88 & 20 & 70 & 79 & 30 & 25 & 100 & 110 \\
\hline T. viride (Tv 5) & 30 & 70 & 77 & 20 & 30 & 35 & 30 & 10 & 150 & 168 \\
\hline Pseudomonas fluorescens & 30 & 60 & 66 & 20 & 0 & 0 & 20 & 15 & 70 & 79 \\
\hline Pseudomona. putida & 40 & 90 & 99 & 30 & 100 & 110 & 40 & 30 & 200 & 220 \\
\hline Basillus subtilis & 35 & 85 & 100 & 20 & 60 & 66 & 30 & 25 & 180 & 189 \\
\hline Rizolex-T 50\% & 30 & 80 & 89 & 20 & 50 & 55 & 30 & 20 & 110 & 121 \\
\hline Control & 50 & 200 & 220 & 35 & 200 & 230 & 60 & 40 & 350 & 400 \\
\hline
\end{tabular}

*A.f $=$ A. flavus ${ }^{* *} \mathbf{A F T}=$ aflatoxin

Data in Table (4) also indicate that the effect of Rizolex-T was not the best in reducing the frequency of aflatoxigenic fungi and peanut seed contaminations with aflatoxin but the mixture of $P$. fluorescens and $T$. viride (Tv 5) gives the best effect.

\section{Evaluation of biocontrol agents under field conditions:}

4.1. On peanut pod rots incidence:

Data in Tables (5 and 6) indicate that all tested biocontrol agents and their mixtures had a significant effect in reducing peanut pod rots incidence during the two successive seasons, 2017 and 2018.

In general $P$. fluorescens showed greater influence in the reduction of all types of pod rot and increased apparent healthy either as single or as mixed application during the two successive seasons, 2017 and 2018.

Moreover, $P$. fluorescens when mixed with $T$. viride (Tv 5) recorded the highest effect in reducing pod rots disease compared with that being mixed with $T$. harzianum (Th 6) along with increasing the percentage of apparent healthy peanut pods during the two seasons, 2017 and 2018. The mixture of $T$. viride (Tv 5) also with B. subtilis or P. putida gave more effective in reducing peanut pod rots during 2017 and 2018 while, the mixed of T. harzianum (Th 6) with other bacterial species gave weak effect in reducing of peanut pod rot Tables( 5 and 6 ).

4.2. On the frequency of $\boldsymbol{A}$. flavus, $\boldsymbol{A}$. parasiticus and peanut seed contaminations with aflatoxin:

In general the frequency of $A$. flavus was higher than A. parasiticus in all treatments during the two growing seasons 2017 and 2018 (Table 7). Data also indicate that the compatible between fungi and bacteria led to more effective in reducing the frequency of aflatoxigenic fungi and seed content of aflatoxin whether total aflatoxin or $\mathrm{B}_{1}$. In this respect compatible with $P$. fluorescens and fungi gives the highest effect on reducing of the frequency of aflatoxigenic fungi as well as peanut seed contamination with aflatoxin followed by $B$. subtilis while the mixture with $P$. putida gives the lowest effect. 
Table 5: Effect of biocontrol agents on peanut pod rots incidence under field conditions during season 2017

\begin{tabular}{|c|c|c|c|c|}
\hline \multirow[b]{2}{*}{ Biocontrol agents } & \multicolumn{3}{|c|}{ Disease incidence (\%) } & \multirow{2}{*}{$\begin{array}{c}\text { Apparent } \\
\text { healthy } \\
(\%)\end{array}$} \\
\hline & $\begin{array}{c}\text { Dry brown } \\
\text { lesion }\end{array}$ & $\begin{array}{c}\text { Pink } \\
\text { discoloration }\end{array}$ & $\begin{array}{c}\text { General } \\
\text { breakdown }\end{array}$ & \\
\hline T.harzianum (Th 6) + P. fluorescens & 7.72 & 0.50 & 11.93 & 79.85 \\
\hline T.harzianum (Th 6) $+P$. putida & 11.03 & 1.01 & 14.60 & 73.36 \\
\hline T.harzianum (Th 6)+B. subtilis & 9.15 & 0.77 & 13.83 & 76.25 \\
\hline T. harzianum (Th 6) & 10.00 & 0.42 & 13.77 & 75.81 \\
\hline$T$. viride $(\mathrm{Tv} 5)+P$. fluorescens & 6.74 & 0.12 & 8.75 & 84.39 \\
\hline$T$. viride $(\mathrm{T} v 5)+P$. putida & 9.27 & 0.24 & 13.03 & 77.46 \\
\hline$T$. viride $(\mathrm{Tv} 5)+B$. subtilis & 7.67 & 0.30 & 11.18 & 80.85 \\
\hline T. viride (Tv 5) & 8.56 & 0.33 & 11.37 & 79.74 \\
\hline Pseudomonas fluorescens & 8.21 & 0.30 & 10.79 & 80.70 \\
\hline Pseudomona. putida & 11.79 & 1.13 & 14.79 & 72.29 \\
\hline Basillus subtilis & 10.57 & 0.83 & 12.36 & 76.24 \\
\hline Rizolex-T 50\% & 5.16 & 0.19 & 7.75 & 86.90 \\
\hline Control & 12.96 & 1.89 & 15.30 & 69.85 \\
\hline L.S.D. 5\% & 1.26 & 0.06 & 1.25 & 1.55 \\
\hline
\end{tabular}

Table 6: Effect of biocontrol agents on peanut pod rots diseases under field conditions during season 2018

\begin{tabular}{|c|c|c|c|c|}
\hline \multirow[b]{2}{*}{ Biocontrol agents } & \multicolumn{3}{|c|}{ Disease incidence (\%) } & \multirow{2}{*}{$\begin{array}{c}\text { Apparent } \\
\text { healthy } \\
(\%)\end{array}$} \\
\hline & $\begin{array}{c}\text { Dry brown } \\
\text { lesion }\end{array}$ & $\begin{array}{c}\text { Pink } \\
\text { discoloration }\end{array}$ & $\begin{array}{c}\text { General } \\
\text { breakdown }\end{array}$ & \\
\hline T.harzianum (Th 6)+P. fluorescens & 8.09 & 0.46 & 11.06 & 80.39 \\
\hline T.harzianum (Th 6)+P. putida & 10.23 & 0.94 & 12.61 & 76.22 \\
\hline T.harzianum (Th 6)+B. subtilis & 8.49 & 0.71 & 11.90 & 78.90 \\
\hline T. harzianum (Th 6) & 9.27 & 0.39 & 11.84 & 78.50 \\
\hline$T$. viride $(\mathrm{Tv} 5)+P$. fluorescens & 6.25 & 0.11 & 8.11 & 85.53 \\
\hline$T$. viride $(\mathrm{Tv} 5)+P$. putida & 8.60 & 0.22 & 12.08 & 79.10 \\
\hline T. viride (Tv 5)+B. subtilis & 7.11 & 0.28 & 10.37 & 82.24 \\
\hline T. viride (Tv 5) & 7.94 & 0.31 & 10.54 & 81.21 \\
\hline Pseudomonas fluorescens & 7.61 & 0.28 & 10.01 & 82.10 \\
\hline Pseudomona. putida & 10.01 & 1.05 & 12.79 & 76.15 \\
\hline Basillus subtilis & 8.87 & 0.77 & 11.53 & 78.83 \\
\hline Rizolex-T 50\% & 4.79 & 0.18 & 7.19 & 87.84 \\
\hline Control & 12.00 & 1.73 & 15.19 & 71.08 \\
\hline L.S.D. 5\% & 1.21 & 0.05 & 1.23 & 1.49 \\
\hline
\end{tabular}

Table 7: Effect of biocontrol agents on the frequency of $A$. flavus, A. parasiticus and aflatoxin contaminations in peanut seed under field conditions during the two growing seasons 2017 and 2018.

\begin{tabular}{|c|c|c|c|c|c|c|c|c|}
\hline \multirow[b]{3}{*}{ Biocontrol agents } & \multicolumn{4}{|c|}{2017} & \multicolumn{4}{|c|}{2018} \\
\hline & \multirow{2}{*}{$\begin{array}{l}\text { A. f. } \\
(\%)\end{array}$} & \multirow{2}{*}{$\begin{array}{c}\text { A. p. } \\
(\%)\end{array}$} & \multicolumn{2}{|c|}{ Aflatoxin (ppb) } & \multirow{2}{*}{$\begin{array}{l}\text { A. f. } \\
(\%)\end{array}$} & \multirow{2}{*}{$\begin{array}{c}\text { A. p. } \\
(\%)\end{array}$} & \multicolumn{2}{|c|}{ Aflatoxin (ppb) } \\
\hline & & & $\mathbf{B}_{1}$ & $\begin{array}{l}\text { Total } \\
\text { AFT }\end{array}$ & & & $\mathbf{B}_{1}$ & $\begin{array}{l}\text { Total } \\
\text { AFT }\end{array}$ \\
\hline T.harzianum (Th 6)+P. fluorescens & 15 & 0 & 80 & 88 & 10 & 0 & 0 & 0 \\
\hline T.harzianum (Th 6) + P. putida & 25 & 20 & 180 & 218 & 20 & 10 & 120 & 132 \\
\hline T.harzianum (Th 6) + B. subtilis & 20 & 15 & 160 & 178 & 15 & 10 & 70 & 77 \\
\hline T. harzianum (Th 6) & 20 & 20 & 100 & 110 & 20 & 15 & 60 & 67 \\
\hline T. viride (Tv 5)+P. fluorescens & 10 & 0 & 0 & 0 & 0 & 0 & 90 & 99 \\
\hline$T$. viride $(\mathrm{Tv} 5)+P$. putida & 20 & 15 & 150 & 165 & 20 & 15 & 100 & 112 \\
\hline T. viride $(\operatorname{Tv} 5)+B$. subtilis & 15 & 10 & 80 & 88 & 10 & 5 & 0 & 0 \\
\hline T. viride ( $\mathrm{Tv} 5)$ & 25 & 20 & 90 & 100 & 15 & 10 & 50 & 56 \\
\hline Pseudomonas fluorescens & 15 & 5 & 0 & 0 & 5 & 0 & 0 & 0 \\
\hline Pseudomona. putida & 30 & 20 & 150 & 160 & 20 & 20 & 140 & 150 \\
\hline Basillus subtilis & 25 & 20 & 110 & 120 & 20 & 15 & 80 & 88 \\
\hline Rizolex-T 50\% & 20 & 15 & 50 & 55 & 15 & 15 & 0 & 0 \\
\hline Control & 40 & 30 & 270 & 300 & 30 & 25 & 200 & 223 \\
\hline
\end{tabular}


In the case of separate treatment, $P$. fluorescens followed by $T$. viride (Tv 5 ) and B. subtilis give the highest reduction of the frequency of aflatoxigenic fungi as well as peanut seed content of aflatoxin. Data also indicate that the effect of Rizolex-T was not the best in reducing the frequency of aflatoxigenic fungi and peanut seed contaminations but the mixture of $P$. fluorescens and $T$. viride (Tv 5 ) gives the best effect during the seasons 2017 and 2018.

\section{Effect of a biocontrol agent on peanut pod yield under field conditions:}

Data presented in Table (8) demonstrate that all tested biocontrol agents either single or in combination caused a significant increase in total peanut pod yield. Percentage of increases however reached (10.94-22.48) and (10.17-29.25) in the first and second seasons respectively.

The highest pod yield in the two seasons obtained with mixed of T. viride (Tv 5) and B. subtills, followed by $T$. viride (Tv 5) and P. fluorescens compared with other biocontrol agents. While RizolexT gave the highest pod yield at all as well as their effect on increase yield in the two successive seasons 2017 and 2018 compared with other treatments. On the other hand, the mixture of Trichoderma viride and B. subtilis was the nearest biocontrol agent to fungicides (Rizolex-T) effect in increase of pod yield in the two seasons 2017 and 2018 compared with other biocontrol agents while T. harzianum (Th 6) gives the lowest effect in increase of pod yield compared with other biocontrol agents in the two seasons (Table 8).

Table 8: Effect of biocontrol agents on peanut yield and increase of yield under field conditions during the two growing seasons 2017 and 2018.

\begin{tabular}{|c|c|c|c|c|}
\hline \multirow[b]{2}{*}{ Biocontrol agents } & \multicolumn{2}{|c|}{2017} & \multicolumn{2}{|c|}{2018} \\
\hline & $\begin{array}{r}\text { Yield } \\
\text { (Ton) }\end{array}$ & $\begin{array}{c}* \text { Increases } \\
(\%)\end{array}$ & $\begin{array}{r}\text { Yield } \\
\text { (Ton) }\end{array}$ & $\begin{array}{c}* \text { Increases } \\
(\%)\end{array}$ \\
\hline T.harzianum (Th 6)+P. fluorescens & 1.338 & 15.25 & 1.395 & 16.25 \\
\hline T.harzianum (Th 6) $+P$. putida & 1.302 & 12.14 & 1.358 & 13.17 \\
\hline T.harzianum (Th 6)+B. subtilis & 1.355 & 16.71 & 1.402 & 16.83 \\
\hline T. harzianum (Th 6) & 1.288 & 10.94 & 1.322 & 10.17 \\
\hline T. viride (Tv 5) $+P$. fluorescens & 1.366 & 17.66 & 1.432 & 19.33 \\
\hline T. viride $(\mathrm{Tv} 5)+P$. putida & 1.300 & 11.97 & 1.392 & 16.00 \\
\hline T. viride (Tv 5)+B. subtilis & 1.396 & 20.24 & 1.485 & 23.75 \\
\hline T. viride (Tv 5) & 1.305 & 12.40 & 1.365 & 13.75 \\
\hline Pseudomonas fluorescens & 1.315 & 13.26 & 1.378 & 14.83 \\
\hline Pseudomona. putida & 1.299 & 11.89 & 1.353 & 12.75 \\
\hline Basillus subtilis & 1.319 & 13.61 & 1.371 & 14.25 \\
\hline Rizolex-T 50\% & 1.422 & 22.48 & 1.551 & 29.25 \\
\hline Control & 1.161 & -- & 1.200 & -- \\
\hline L.S.D. 5\% & 0.053 & & 0.049 & \\
\hline
\end{tabular}

*Increases related to the control

\section{Discussion}

Biological control of plant pathogens by microorganisms decreases the use effect of fungicides hazardous to humans and the environment (Cook, 1993).

The present study results indicated that the tested biocontrol agents significantly reduced peanut pod rot disease, occurrences of aflatoxigenic fungi (A. flavus and A. parasiticus) and seed content of aflatoxin whether under artificial infection or natural infection and showed antagonistic effect against the tested pathogeneses fungi in vitro. Regarded to this, Pseudomonas fluorescens (Pf5) followed by Trichoderma viride (Tv5) and Bacillus subtilis (Bs1) gave the highest significant antagonistic effect against the tested pathogen growth. These results are in harmony with those reported Mishra et al., (2011\&2013), Mahmoud et al., (2016), Kifle et al., (2016), Bhimeshwari et al., 2018 and Wang et al., (2018).

Who's reported that $B$. subtilis and $P$. fluorescens, as well as Trichoderma viride, were found to be the most effective biocontrol agent against various soilborne diseases caused by $F$. moniliforme, $F$. solani R. solani, M. phaseolina, S. rolfsii, A. flavus, and A. parasiticus, and other. On the other hand, Torres et al. (2014) confirmed the use of biocontrol agents to reduce Aspergillus contamination of crops pre-harvest. While, Mahmoud, (2004), reported that, Under field condition, Bacillus spp. (Sp2) 
followed by Bacillus spp. (Ss2) and Pseudomonas fluorescens (Pf 5) had a significant effect on reduced the pod rot incidence and recorded the highest effect on reduced the occurrence of aflatoxigenic fungi and the aflatoxin contaminations. And in 2014 he stated that, in greenhouse and field experiments, the most effective isolates in reducing peanut damping-off, root and pod rot diseases were $P$. fluorescens (Pf.5) followed by B. subtilis (Bs1) and Brevibacterium carei (S.5). Moreover, Kifle et al. (2016) found that Trichoderma harzianum strain kd can reduce infection of the groundnut seeds by Aspergillus flavus, and hence it may reduce the contamination of the seed by aflatoxin, especially under drought stress condition.

Many studies in this respect showed that certain P. fluorescens and B. subtilis isolates were effective rhizobacteria for suppression of soil-borne fungi, by production of certain substance such as enzymes, phenazines, pyrrole type antibiotics, pyo-compounds, indole derivatives peptide antibiotic, moenomycins, difficidins, bacillomycins and bacillaenes (Bhimeshwari et al., 2018 and Wang et al.,2018). Moreover, certain strains of Pseudomonas can produce several siderophores such as pyoverdine (pseudobactin) pyochelin, pyrollnitrin (antibiotic), salicylic acid, HCN and lytic enzymes (Bhimeshwari et al., 2018). Also, B. subtilis can induce resistance by stimulation of phytoalexins production and increasing the activity of lytic enzymes (Wang et al., 2018). While, Trichoderma isolates can be antagonistic on other fungi through lyses to host hyphae by the action of hydrolytic enzymes such as chitinases, beta-glucanases and proteases alone or in combination with secondary metabolites also, it competition for nutrients by produce siderophores basically concentrates on carbon, nitrogen and essential micronutrients such as iron and manganese (Muhammad et al., 2018).

The present study is in agreement with the studies conducted by different workers, where they have reported that increased biocontrol activity might be achieved by combining different isolates of biocontrol agents (Duffy et al., 1996; Raupach and Kloepper, 1998). Further, Duffy et al., (1996) indicated that $P$. fluorescent species and $T$. koningii are compatible when applied to wheat simultaneously. The performance of all bacterial treatments was greatly enhanced by combination with T. koningii. While, Mishra et al., (2013) reported that, Trichoderma harzianum and Pseudomonas fluorescens when tested alone or combined under glass-house and field conditions against many soilborne plant pathogens viz., Rhizoctonia solani, Sclerotium rolfsii and Macrophomina phaseolina responsible for root and stem rot disease of soybean give a greater suppression and enhanced consistency against the pathogens by mixed of them. However, Mahmoud et al., (2016) stated that the mixed with $T$. viride either with $B$. subtilis or $P$. fluorescens revealed greater effect in control of sunflower charcoal rot compared to the single application of any of them, especially the mixed with $B$. subtilis treatment.

These results strengthen the opinion that control with fungicides can be partially replaced by biological control because it's effectively protected the peanut pod from aflatoxigenic fungi and aflatoxin contamination. The results clearly showed that Rizolex-T was not the best in reducing the frequency of aflatoxigenic fungi and peanut seed contaminations but the mixture of $P$. fluorescens and T. viride (Tv 5) record the best effect during the seasons 2017 and 2018.

\section{References}

Bhimeshwari S., S. Jahaar, S. Girija and A. Pradhan, 2018. Pseudomonas fluorescens PGPR bacteria as well as biocontrol agent: A review. International Journal of Chemical Studies 6(2): 01-07.

Calvo, A.M. and J.W. Cary, 2015. Association of fungal secondary metabolism and sclerotial biology. Frontiers in Microbiology 6.

Cook, R.J., 1993. Making greater use of introduced microorganisms for biological control of plant pathogens Annu. Rev. Phytopathol., 31: 53-80.

CoStat, 2005. CoStat program, version 6.4. CoHort software, Monterey, CA, USA.

Datnoff, L.E., S. Nemec and K. Pernezny, 1995. Biological control of Fusarium crown and root rot of tomato in Florida using Trichoderma harzianum and Glomus intraradices. Biol. Control, 5:427431.

Duffy, B.K., A. Simon and D.M. Weller, 1996. Combinations of Trichoderma koningii and fluorescent pseudomonad for control of take-all of wheat. Phytopathology, 86:188-194.

Felicia, W., Yan, L., and B. Deepak, 2008. Cost-effectiveness of aflatoxin control methods: Economic incentives. Toxin Reviews, 27(3\&4):203-225. 
Hawkins, N.J., C. Bass, A. Dixon, and P. Neve, 2018. The evolutionary origins of pesticide resistance. Biol. Rev. Camb. Philos. Soc. 94, 135-155. doi: 10.1111/ brv.12440

Kifle, M.H., K.S. Yobo and. M.D. Laing, 2016. Biocontrol of Aspergillus flavus in groundnut using Trichoderma harzianum stain kd Journal of Plant Diseases and Protection -New Series- . December 2016 DOI: 10.1007/s41348-016-0066-4.

Mahmoud, E.Y., 2004. Integrated control of pod rot diseases of peanut. Ph.D. Thesis, Fac. Of Agric, Ain - Shams Univ. $154 \mathrm{pp}$

Mahmoud, E.Y., 2014. Performance of some antagonistic bacteria in minimizing occurrence of peanut damping - off, root and pod rot diseases. Egypt j. Phytopathol. 42 (1):205-220

Mahmoud, E.Y., and M.G. Ahmed, 2015. Impact of some essential plant oils for controlling of peanut pod rots diseases and aflatoxin. J. Biol. Chem. \& Envirom. Sci., 10 (1): 261-280.

Mahmoud, E.Y., M.M. Ibrahim, Wagida A.M. Saleh and M.I.M. Ahmed, 2016. Compatibility between antagonistic fungi and bacteria and their influence in controlling sunflower charcoal rot. Egypt J. Phytopathol., 43(1-2): 53-65

Malone, B.R., C.W. Humphrey, T.R. Romer, and J.L. Richard, 2000. Determination of Aflatoxins in Grains and Raw Peanuts by a Rapid Procedure with Fluorometric Analysis. Journal of aoac International, 83: 95-98.

Maren, A.K. and I.P. Johan, 1988. A laboratory guide to the common Aspergillus Species and Their Teleomorph. Commonwealth Scientific and Industrial Res. Org. Division of Food Processing., $116 \mathrm{pp}$.

Mishra, D.S., A.K. Gupta, C.R. Prajapati and U.S. Singh, 2011. Combination of fungal and bacterial antagonists for management of root and stem rot disease of soybean Pak. J. Bot., 43, 25692574.

Mishra, D.S., A. Kumar, C.R. Prajapati, A.K. Singh and S.D. Sharma, 2013. Identification of compatible bacterial and fungal isolates and their effectiveness against plant disease. J. of Environmental Biology, 34:183-139.

Mossanda, K.S., 2015. Hepatocellular carcinoma: Putative interactive mechanism between aflatoxins and hepatitis viral infections implicating oxidative stress during the onset and progression of cancer. Hypothesis 1: 18.

Muhammad, U., M.R. Ghazanfar, R. Waqas, and I.Q. Misbah 2018. Trichoderma as potential biocontrol agent, its exploitation in agriculture: A review. Plant Protection, 02 (03):109-135

Ng, A., D. Weerakoon, E. Lim, and L.P. Padhye, 2019. Fate of environmental pollutants. Water Environ. Res. 91, 1294-1325. doi: 10.1002/wer.1225

Price, C.L., J.E. Parker, A.G. Warrilow, D.E. Kelly, and S.L. Kelly, 2015. Azole fungicides understanding resistance mechanisms in agricultural fungal pathogens. Pest Manag. Sci. 71, 1054-1058. doi: $10.1002 /$ ps.4029

Raupach, G.S. and J.W. Kloepper, 1998. Mixtures of plant growth promoting rhizobacteria enhance biological control of multiple cucumber pathogens. Phytopathology, 88:1158-1164.

Torres, A., G. Barros, S. Palacios, S. Chulze and P. Battilani, 2014. Review on pre-and post-harvest management of peanuts to minimize aflatoxin contamination. Food Research International 62: 11-19.

Wang, X.Q., D.L. Zhao, L.L. Shen, C.L. Jing, and C.S. Zhang, 2018. Application and mechanisms of Bacillus subtilis in biological control of plant disease,", in Role of Rhizospheric Microbes in Soil: Volume 1: Stress Management and Agricultural Sustainability, ed. V. S. Meena (Singapore: Springer Singapore), 225-250. 